\title{
After the Stasi
}




\author{
Also available from Bloomsbury \\ Beyond Discontent: 'Sublimation' from Goethe to Lacan, Eckart Goebel \\ From Kafka to Sebald, Sabine Wilke \\ German Unification: The Unexpected Challenge, Dieter Grosser
}




\title{
After the Stasi: Collaboration and the Struggle for Sovereign Subjectivity in the Writing of German Unification
}

\author{
Annie Ring
}

Bloomsbury Academic

An imprint of Bloomsbury Publishing Plc

B $\quad$ L LONDON • OXFORD • NEW YORK • NEW DELHI - SYDNEY 


\title{
Bloomsbury Academic
}

An imprint of Bloomsbury Publishing Plc

\author{
50 Bedford Square $\quad 1385$ Broadway \\ London New York \\ WC1B 3DP NY 10018 \\ UK USA
}

www.bloomsbury.com

\section{BLOOMSBURY and the Diana logo are trademarks of Bloomsbury Publishing PIc}

First published 2015

(C) Annie Ring, 2015

Annie Ring has asserted her right under the Copyright, Designs and Patents Act, 1988, to be identified as Author of this work.

All rights reserved. No part of this publication may be reproduced or transmitted in any form or by any means, electronic or mechanical, including photocopying, recording, or any information storage or retrieval system, without prior permission in writing from the publishers.

No responsibility for loss caused to any individual or organization acting on or refraining from action as a result of the material in this publication can be accepted by Bloomsbury or the author.

\section{British Library Cataloguing-in-Publication Data}

A catalogue record for this book is available from the British Library.

$$
\begin{aligned}
& \text { ISBN: HB: 978-1-4725-6760-4 } \\
& \text { ePDF: 978-1-4725-6762-8 } \\
& \text { ePub: 978-1-4725-6761-1 }
\end{aligned}
$$

\section{Library of Congress Cataloging-in-Publication Data}

A catalog record for this book is available from the Library of Congress.

Typeset by Fakenham Prepress Solutions, Fakenham, Norfolk NR21 8NN

Printed and bound in Great Britain 
For Barbara and Patrick Ring 



\section{Contents}

List of Illustrations $\quad$ ix

Acknowledgments $\quad$ xi

Note on the Text

Introduction: Collaboration and the Problem of Sovereign Subjectivity 1

1 The Psychic Life of Collaboration: Monika Maron's Stille Zeile Sechs

2 Mapping the Topography of Surveillance in Wolfgang Hilbig's "Ich" and Kerstin Hensel's Tanz am Kanal

3 Collaboration as Collapse in the Stasi Files and Life Writing of Monika Maron and Christa Wolf 97

4 Prison/Writing: The Subject of the Stasi Archive 129

5 Animals and the Limits of Sovereignty in the Writing of Unified Germany 165

6 Capitalist Complicity in Wolfgang Hilbig's Last Prose Works 199

Conclusion: After the Stasi. Complicity and Cooperation 227

Works Cited 243

Index 255 


\section{Illustrations}

Fig. 1 "Meßblatt" (measuring-sheet) for new detainees of the Stasi.

From MfS, HA IX, Nr. 16034, p. 95.

Fig. 2 Student notes from the seminar "Personenidentifizierung" (the identification of persons) at the Juristische Hochschule in 1984. From BStU, MfS, HA IX, Nr. 9657, p. 45.

Fig. 3 Interview in 1989 with a mother of a detainee in Rostock. From BStU, MfS, AU 457/93, Vol. 4, p. 128.

Fig. 4 Page from Wolfgang Hilbig's GDR Ausweise für Arbeit und Sozialversicherung (identity documents for work and social insurance). From Wolfgang-Hilbig-Archiv, Nr. 285. 


\section{Acknowledgments}

The Arts and Humanities Research Council funded the doctoral project at University of Cambridge on which research this monograph is partially based. Emmanuel College, Cambridge, awarded me the Research Fellowship that enabled me to transform that project into this monograph. Finally, a grant from the Cambridge Humanities Research Grants Scheme allowed me to complete my final research in the archive of the Federal Commissioner for the Stasi Files (BStU). I am grateful to Christian Schwack and Raphaela Schröder for their assistance in the BStU archive and to Barbara Heinze at the Literature Archive of the Akademie der Künste. I presented chapters of the book in preparation at the German Department Research Seminar, University of Leeds; at the German Studies Association Conference in Denver; at the inaugural conference of the Negotiating (In)Visibilities network, held at the Department of Arts and Cultural Studies, University of Copenhagen; and at the Research Seminar in German Studies at King's College London.

I would like to thank Andrew Webber, whose mentorship I have been privileged to enjoy throughout the duration of this project, as well as the many other colleagues and friends who commented on chapters in preparation.

Parts of Chapter 4 appeared in the journal article "The (w)hole in the archive," Paragraph, 37, and are reprinted by permission of Edinburgh University Press. Sections of Chapter 3 will be published in an abridged version in a volume on secret police files, edited by V. Glajar, A. Lewis, and C. Petrescu and forthcoming with Camden House. The extract from "Porträt des Künstlers als junger Grenzhund" is reproduced by permission of the copyright holder, Suhrkamp Verlag, the pages from the Stasi archive appear by permission of the Federal Commissioner for the Stasi Files (BStU), and the image from Wolfgang Hilbig's GDR passbook is reprinted by permission of the S. Fischer Stiftung. 


\section{Note on the Text}

Translations from Stasi files and literary works in German are my own except where otherwise stated. 


\section{Introduction: Collaboration and the Problem of Sovereign Subjectivity}

Twenty-five years after the disbandment of the East German Ministerium für Staatssicherheit (Ministry for State Security; Stasi), the question remains as to why so many citizens of the former German Democratic Republic (GDR) agreed to collaborate with the Stasi as unofficial spies. The Stasi's demise and the opening of its vast archive brought to light the collaboration by ordinary East Germans as Inoffizielle Mitarbeiter (unofficial informants; IMs) for the Ministry. The revelations in front-page scandals and in speeches by prominent public figures tended to cast the former IMs as co-perpetrators in a totalitarian regime of power. Wolf Biermann, in his acceptance speech for the Georg Büchner Literature Prize of 1991, in which he outed the star underground poet Sascha Anderson as a Stasi informant, spoke damningly of IMs as the "Kreaturen" (creatures) which the East German state had set "an die Spitze der Opposition, um sie besser abbrechen zu können" (at the very top of the opposition, in order to lop it off it more effectively; Biermann, 1991, unpaginated). Biermann's language indicated a contempt for those who had permitted themselves to be subjugated by the Stasi as mere "creatures." The West German press meanwhile relished uncovering the IM pasts of such former supporters of socialism as Heiner Müller and Christa Wolf, at the same time as celebrating the advent of capitalist liberal democracy in the East. By contrast, though the literary sphere in the GDR had been saturated with informants, literary writing by East Germans after 1990 has dealt more ambivalently with the phenomenon of IMs, and with the questions of subjectivity in relation to power that it raised. Those literary works, by GDR-born writers publishing after the fall of the Berlin Wall, and after the Stasi, are the concern of this book.

Alongside the outcries in press and public discourse, a body of literary work has emerged since 1990 that offers a more nuanced and ultimately more 
helpful account of life under the Stasi, moreover one that affords insight into broader problems of society and subjectivity which go beyond the history of the spy organization itself. These works include life writing, fiction, and a crossover genre of "autofiction," by authors who had encountered the Stasi in their lifetimes, all of them as victims of its surveillance at some point, and many of them as spies themselves. Due to the intimate experience of their authors with the Ministry, these texts are uniquely placed to assess its operations and their effects. In particular, they offer a perspective on the interaction that the now-defunct secret police had with a subjectivity that in this body of writing is conceived as susceptible to the coercive structures that define collaboration and therefore not unproblematically guilty of it. In contrast to a public discourse that was dominated in the 1990s by clear-cut categories of victimhood and perpetration, power and subjection, totalitarianism and democracy, what many of these works have in common is the presence of core characters who cannot be categorized or defined. Nor do they make up self-defined, sovereign subjects in their own right. Instead, they are subject to the power of others, and even to other powers within themselves, in ways that both enable and complicate the collaborations that they carry out. These may be the collaborations that they enter into with the Stasi, or they may be certain new participations that take place in its aftermath, in the newly unified Germany. For, crucially, the challenge posed by these works is to see that such susceptibility to collaboration, the result of an ultimate lack of sovereignty in the subject of modernity more broadly, did not come to an end along with the Cold War.

\section{IMs: The Stasi's unofficial collaborators}

On 30 June 1990, not long before it voted in favor of German unification, the East German Parliament, the Volkskammer, elected to disband the Stasi. For the preceding four decades, the single-Party dictatorship of the Sozialistische Einheitspartei Deutschlands (Socialist Unity Party; SED) had been in power, kept there with the help of a secret police that was tasked with spying on enemies both outside and within the GDR. The months following the mass demonstrations by East German citizens that had led to the fall of the Berlin Wall were dominated by wrangling with this secret service, with which an estimated total of two million people had been involved at some stage since its founding in 1950. Its offices were stormed and occupied by groups of protestors, who chanced upon evidence of an unprecedented surveillance regime. One of 
the most shocking revelations in that time concerned the involvement of East German civilians in the Stasi's operations. It is estimated that in the year 1989 alone around 189,000 unofficial informants, or one in eighty-nine East German citizens (Müller-Enbergs, 2008a, p. 3), were at work supporting the 91,000 officers employed in the Stasi's formal ranks (Dennis, 2003, p. 3). The term "IM," first introduced to the Stasi's in-house vocabulary in 1968 to describe its civilian helpers, came after 1990 to dominate discussions of the demands that the first experiment in establishing state socialism in Germany had placed on its citizens, and of the decisions that those citizens had made when asked to collaborate with the spies who had until recently watched over them.

Though the term "IM" was practically unknown outside of the Stasi until after the Berlin Wall fell, the revelation of the existence of this network of unofficial spies made explicit something that many had long suspected, namely that the ears and eyes of the Ministry had indeed been ever-present in the GDR. However, few had suspected how close the collaborator network had allowed the Stasi to come to the objects of its surveillance, close enough so that even the most private activities had not escaped its pedantic attention. The IM operations were central to the Stasi's security project, as is attested by the resources that it expended to ensure that the right candidates were selected for IM work, and to training commanding officers in the proper techniques for guiding IMs through their surveillance tasks. There was a dedicated university for training Stasi officers, founded in Potsdam in 1951 as the Schule des Ministeriums für Staatssicherheit (School of the Ministry for State Security), and renamed in 1965 the Juristische Hochschule (Legal University). Courses at the Hochschule and a series of Guidelines that were circulated among officers, a first set appearing in 1952 and a final revision of 1979, set out how missions involving IMs were to be run. While unofficial collaborators did not themselves undergo training, they were subject to extensive checking by other spies, via an operation known as the IM-Vorgang (Informant-Procedure), the duration of which was not limited to the time before a collaboration was officially launched.

Such care was taken in the selection, recruitment, and surveillance of its IMs because these civilian informants carried out the work of the Operativer Vorgang (Operative Procedure; OV), a procedure targeted against suspected enemies of the SED-state. IMs were set to work on this crucial component in the Stasi's procedural apparatus, gathering information on victims to whom, as unofficial operatives, they could become particularly close, and thereby secure sufficient evidence of illegal activities for a court case in the Stasi's separate legal system. Such cases could lead to trial, imprisonment, or in rare cases, execution 
(cf. Evans, 1996, p. 861); they could also produce fines, public denunciation, or expatriation, as seen in the case of Wolf Biermann. IMs were also central pawns in the Stasi's Zersetzungsmaßnahmen (measures for subversion; or more literally, taking apart or breaking down), the bullying that took place outside of the Stasi court and prison system, but through which lives were still destroyed, individuals isolated from their loved ones and often forced to remain in the GDR, resigned to the repeated refusal of their applications to travel, work, or attend university, and contemplating the illegal option of Republikflucht (defection to the West).

After the borders to the West were opened in 1989, scrutiny from protestors and international news media compelled the Stasi to reduce its operations rapidly. A strong citizens' movement of East Germans opposed to the Stasi's activities began a series of meetings in early January 1990, coordinating the closing down of the Stasi entirely, and on 15 January around 100,000 demonstrators stormed and occupied its central offices. With German unification, the perpetrators of the SED regime-the Ministers and Commanders who had ordered shootings at the Berlin Wall, the detention of dissidents, and large-scale surveillance of citizens-were brought to account. Erich Mielke had headed the Stasi from 1957 to 1990, and he was put on trial alongside long-time GDR leader Erich Honecker for the deaths of forty-nine people trying to escape to West Berlin over the Wall. After their trial was abandoned due to procedural difficulties, Mielke was tried and sentenced to six years in prison for the murder of two policemen during the pre-Nazi era, while Honecker died in disgraced exile. Among senior Stasi officials, a few decided to end their lives, including regional chiefs Gerhard Lange, Horst Böhm, and Peter Koch, all in the first half of 1990. The lowest-ranking Stasi officers, who were the first to be let go, initially entered sectors of the GDR workforce including border authorities, the Nationale Volksarmee (National People's Army; NVA), and the postal service, and, with unification, were once again some of the first to be made redundant. A disputed number of former Stasi employees was kept on by the Commission responsible for administering the Stasi archive which, as its chief and now Federal President Joachim Gauck admitted, required their bureaucratic skills and familiarity with the files in order to work through the "etliche laufende Meter Aktengut" (many meters of archival material) they had left behind (Gauck, 1991, p. 16).

The destinies of IMs were somewhat different to those of official Stasi employees. The mass demonstrations and storming of the Stasi offices led to insecurity on the part of many, who began en masse to terminate their collaborations with the Stasi in writing, via the usual procedure set out in the archive. 
However, an unknown number continued to submit their spy reports up until the start of December 1989 (cf. Kowalczuk, 2013, p. 344), nearly a month after the Wall fell. As the files that had been uncovered began to be pored over, both of these groups faced their Enttarnung (unmasking) as having spied on fellow citizens. The question that lay behind these Enttarnungen was how the Stasi had been so successful in recruiting its unofficial informants. Why had so many citizens of East Germany agreed to spy on those with whom they lived and worked, and thus to serve a Ministry under which many had themselves suffered as victims of surveillance and Zersetzung? Despite the marked differences between the sensationalism of the post-unification press and the more ambiguous tone of literary writing after 1990, this question united tabloid headlines with the cultural output of East German writers, in a corpus of works that grappled with the Stasi and its legacy in unified Germany.

\section{Collaboration and critique in East German literature}

According to the Stasi Guideline of January 1979, the motives that suitable IMs would exhibit included political and ideological "Überzeugung" (conviction; Müller-Enbergs, 2008a, p. 44), as well as an image of the class enemy compatible with that held by the Stasi, "materiell[e] Bedürfnisse" (material need) and / or some social or intellectual interest in the prospect of collaboration (ibid., p. 44). The Guideline also allowed for a degree of pressure to be placed on potential IMs whose work was considered necessary to the Stasi's missions, pressure resulting from the use of "kompromittierendem Material" (compromising material; ibid., p. 44), defined in the document as information held on the potential informant that could be used to exploit their conscience or insecurities. Research published after unification, by the office of the Bundesbeauftragte für die Unterlagen des Staatssicherheitsdienstes der ehemaligen DDR (Federal Commissioner for the Stasi Files/BStU), also lists the reasons why IMs would have collaborated with the Stasi, including those identified by the Stasi in its Guidelines of conviction and material need, as well as motives that were named by IMs themselves, in interviews after the dissolution of the Stasi, including personal affection for their case officer, deception, and coercion.

An additional angle on the reasons underlying unofficial collaboration was furnished by the literary writing that emerged after unification by East German writers. Following the IM scandals, in a body of work that proved highly successful among the German reading public, many East German authors 
felt compelled to give an account of their own collaboration with the Stasi or, where they had been only victims, an account of the manner in which the secret service had affected their lives. The access that these texts enjoy, as literary works, to narrative modes of testimony and storytelling, to imaginative systems of metaphor and symbolism, and to the complex languages of the inner life of the individual, enable them to give a perspective on the phenomenon of IMs as symptomatic of a fundamental lack of sovereignty in the human subject. This is a perspective which neither the Stasi nor the post-GDR public sphere could quite capture in their vocabularies, formed as they were by political expediency and a leaning towards the scandalous when dealing with the recent past.

Peter Graves has noted an expectation among the German reading public that contemporary literature in German should "work through" the historical and political past from which it emerges (Graves, 2002, p. 146). Indeed, after the fall of the Berlin Wall, German literary critics and readers awaited with bated breath the novel that would capture the mood of German unification, give an account of the GDR's demise, and help the reading public to process the recent past. Contrary to the scandal-focused public discourses of the time, the most successful works of the post-unification moment were those that offered more nuanced accounts of the conditions of surveillance, and thus uncovered the imperative to collaborate that the SED regime imposed on citizens of the GDR with few exceptions. These literary retellings of the recent past contributed to a process that came to be known as Aufarbeitung (working through the past), which extended beyond the project of Vergangenheitsbewältigung (overcoming the past) that had been attempted in West German public discourses and cultural production after the Nazi era. Post-GDR Aufarbeitung included the work of Gauck's Commission, the "BStU" or Stasi Records Agency that was set up to work through the Stasi's archival legacy; it also took in the court cases against perpetrators, and the slower, as yet still unfinished process of reconciliation in unified German society.

Of particular interest for their accounts of collaboration and victimization under the Stasi are the works of Monika Maron (born Monika Iglarz, Berlin 1941) and Wolfgang Hilbig (born Meuselwitz 1941, died Berlin 2007), authors who shared the experience of having their writing censored in the GDR and published to great acclaim in West Germany. Although they are little known outside of Germany, and Hilbig's works have yet to be published in English translation, the historical relationships of these two authors with the Stasi afford them rare insight into its operations with regard to IMs. In the following chapters, their novels and short stories, a selection of Hilbig's many 
poems, essays by Maron, and both authors' Frankfurt Poetics Lectures are set in dialogue with a rich array of works by other authors from the former East published after 1990. These include texts by the renowned authors Christa Wolf (1929-2011) and Erich Loest (1926-2013), and the award-winning writers of younger generations Eugen Ruge (b. 1954), Kerstin Hensel (b. 1961) and Durs Grünbein (b. 1962). Certain texts are also included that were published in the West by East German authors before the Stasi had been dissolved, including Maron's first novel Flugasche (Flight of Ashes, 1981), which was written in part during her collaboration with the Stasi, and some of Hilbig's earliest writings from immediately after his detention in Stasi interrogation prison.

These literary works give account of the motives that led to unofficial collaboration, including those arising from that ideological agreement that the Stasi named as desirable in its recruitment procedure, as well as from the coercion that the BStU interviews brought to light. Yet there are three further motivations that these texts "propose" as underlying collaboration. The first of these is a legacy from Nazi Germany, in which attachment to the authority of a leader expresses itself in participation by individuals in violent regimes. Consonant with the argument of Alexander and Margarete Mitscherlich, that West Germany had failed to mourn, and thus overcome its Nazi past after 1945 (cf. Mitscherlich and Mitscherlich, 1967), this first motive for IM work as depicted in the literary works corresponds to an "alte Gewohnheit" (old habit) of self-subjection to leader-figures, a remnant from habits of the Nazi era that was flagged in some of the first interviews with IMs (Riecker et al., 1990, p. 163), but largely passed over in the perpetrator-hunts of the 1990s. Far from excluded, this bad habit instead appears in the literary writing of German unification as dying hard, or indeed as living on as a past still unmastered, that finds critical expression in the characters who appear in a number of works, literary figures of outright violence or subtler suppression, with whom collaboration is oddly impossible to refuse.

Psychoanalysts Ingrid Kerz-Rühling and Tomas Plänkers have proposed that a further motive for becoming an IM was a "Sehnsucht nach Anerkennung" (longing for recognition; Kerz-Rühling and Plänkers, 2004, p. 8), recognition that may have promised more adventure than everyday life in the GDR held, and perhaps the possibility of promotion in one's career through agreement to do what Mielke's organization demanded. This proposition is compatible with a second motive depicted in the literary works discussed here, whose characters long for status and subjecthood, for adventure and the opportunity to do the work that they love, as well as the reward of being acknowledged by others. 
A third motive that these works reveal is a desire for "Geborgenheit" (safety) that was also identified by Kerz-Rühling and Plänkers (ibid., p. 8). This third motive suggests a hope among collaborators that the Ministry that operated under the sign of Sicherheit (security) could offer protection for them, not least against victimization by that same Ministry. Representing a more collective kind of security, collaboration also necessarily meant access to those in power, in whose presence the committed collaborator might be able to criticize and thus protect the socialist state, in particular for those who wished to see the habits of the Nazi past overcome once and for all. This latter desire, to critique and thereby protect the East German state from within, was particularly strong among those left-wing intellectuals and authors who collaborated with the Stasi while they still believed in the potential for socialism in the GDR. This, and the less intellectual desires for protection and recognition are the three core motives for IM work as East German writers have portrayed them after 1990. The implications of these motives are handled, moreover, in literary plots that critically explore the consequences of following such desires or rationalizations for collaboration with a body of power such as the Stasi.

That literary writing should perform a critical role is by no means unfamiliar to readers of East German writing. Instead, much earlier East German literature that adopted a position of critique had itself entered into a degree of collaboration in the fallen SED regime. Lenin's recommendation that literature should facilitate the development of traditions and role models for socialist living, and Stalin's subsequent ideal of writers as "engineers of the human soul" (cited by Emmerich, 2005, p. 43), had led USSR state policy from the early 1930s to require that writers produce texts in a mode known as Socialist Realism. The SED's cultural policy carried this model over into the GDR, requiring literary prose whose simplicity would make it accessible to the masses, with plots featuring the neuer Mensch (new person) as a strong, positive hero or heroine, and preferably taking place in realistic socialist settings, especially the factories where the seeds for the experiment in state socialism had been sown. The logic behind this policy was that such a mode of writing would replace the Nazi aesthetic via models of expression with which all readers could identify, as they set about building the new socialist Germany. Yet, despite its origins in the fledgling GDR's project of radical economic transformation, Socialist Realist writing as produced by conformist writers in the early years suffered from a prose that was tediously "tendenziös" (tendentious; Herminghouse, 1979, p. 288), and plots whose idealism was too uniform to be inspiring. The figure of the neuer Mensch produced an image that, rather than being critical, instead 
generated a new norm for the industrial productivity pushed for by the struggling state. To make matters worse, as the plots of most of these works failed to offer new models for a different kind of living in the socialist family, the mode also generated a norm for a private reproductivity that differed little from what had gone before it, or from the capitalist family in neighboring West Germany.

Writers in the GDR quickly grew dissatisfied producing texts in the strict mode required by the Ministerium für Kultur (Ministry for Culture), and as the gap between ideals and reality gaped ever wider, especially after the intervention by Soviet and GDR troops in the Prague Spring of 1968, they developed newly critical styles that enjoyed varying levels of publication success. Christa Wolf made an attempt to write critically within a mode that was still technically realist, as in her GDR novel Der geteilte Himmel (Divided Heaven, 1963), which was published, though the film version of the following year by director Konrad Wolf was banned from screening in the GDR. A writer of the same generation as Wolf, Irmtraud Morgner, had followed established patterns of content and form in her early work, for example Haus am Rand der Stadt (House on the Edge of the City, 1962), which celebrated women's opportunities in the GDR. However, she broke the mold with her montage-novel Leben und Abenteuer der Trobadora Beatriz nach Zeugnissen ihrer Spielfrau Laura (The Life and Adventures of Troubadour Beatrice as Chronicled by Her Minstrel Laura, 1974), which sidestepped Socialist Realism's single authorial viewpoint in order to weave together stylistic elements of the early modern novel that its extended title cites, as well as an array of narrative voices taken from previously censored work and documentary material. Morgner's fantastic-realist novel enjoyed a wide readership in the GDR thanks to its publication at the highpoint of an era of cultural liberalism, after the replacement of draconian leader Walter Ulbricht with the initially liberal Honecker in 1971, an era that ended with the expatriation of Biermann in 1976 and subsequent crackdown on dissident authors by the Ministerium für Kultur in collaboration with the Stasi.

From the mid-1970s, authors who wished to criticize the SED favored modernist modes of writing, with its uncategorizable patterns of character, plot, language, and symbolism. That this decision usually spelled censorship after 1976 lent even more kudos in the West to such writers, including Maron and Hilbig, both of whom were discovered by the Fischer publishing house in Frankfurt, which was eager to print GDR-critical works. Yet, while the modernist-inflected narratives of Maron, Hilbig, and their peers answered a critical imperative during the GDR years, to find modes of literary expression that went against the dictates of the SED, the status of such narratives underwent 
rapid transformation in the moment of German unification. For now, in the era of the IM scandals, modes of writing that had critically resisted categorization in the GDR risked appearing as deliberate obfuscations of the recent past.

In the months before the Volkskammer voted for German unification, many of the most prominent voices arguing for an improved form of state socialism were also literary writers. The influence in this debate of such authors as Wolf and her counterpart in the GDR's theatre and poetry scenes, Heiner Müller, reflects the importance placed on the arts in the GDR, and these writers appealed for socialist reform alongside the late lead actor of Das Leben der Anderen (The Lives of Others), Ulrich Mühe, and Brecht's granddaughter, actress Johanna Schall, at the mass demonstration on Berlin's Alexanderplatz on 4 November 1989. Yet Graves has claimed the Alexanderplatz rally as the beginning of a crisis in the reputation of the arts, wherein "the notion of the artist as moral guide [...] died" (Graves, 2002, p. 146). Indeed, the calls for an improved socialism were not heeded; instead, within a matter of days, the revolutionary assertion of popular power by the uprising in the East, "wir sind das Volk" (we are the people), became the cry for a unified Germany, "wir sind ein Volk" (we are one people). The subtle switch from a definite to an indefinite article signaled the end of the first socialist state on German soil and also a discrediting of the voices of critical socialist intellectuals. Those who had practiced critique within the GDR, but were now arguing in favor of its continuation in some form, were poised at this point for a fall, which would come for Wolf, Müller, and others along with the revelation of their Stasi collaborations. The crisis in the status of politically engaged art from the East was deepened by the revelations that many of its makers had not only been involved in supporting the East German state in their work, but had also agreed to act as spies for its secret police.

However, although their moral authority may have fallen along with the GDR, the role of artists as commentators on the political events of their era did not perish with it. Instead, in response to the events of German unification, in particular the revelation of the involvement of a number of prominent writers with the Stasi, East German writing after 1990 developed a mode that made space for the public's interest in the biographies of its authors, and thus in the events of the recent past, while maintaining the qualities of creative expression that were particular to the critical literature of the GDR. Karen Leeder has viewed the boom since 1990 in autobiography and memoir, forms in which the onus is on the author to deliver an account of themselves and their actions, as a "fetishization of authenticity" in post-GDR memory culture (Leeder, 2011, p. 200). Yet many authors from the GDR offered resistance to such a fetishization 
in the post-unification moment, as they began to publish texts that cannot be classified as autobiography in the classic sense. Instead, there developed at this time a form that resided somewhere between fact and fiction. It is best characterized as a kind of autofiction, a term coined by the French novelist Serge Doubrovsky to describe the combination of historical fact and literary fictionality that defined his writing in the 1970s. Historical referents in this East German corpus ranged from the use of authors' names or recognizable events from their lives in semi-fictional plots, to the inclusion of Stasi terminology and in some cases reproductions of Stasi files within texts marketed as novels, devices which breached the boundaries between memoir and literary fiction.

This new mode of post-unification autofiction allowed authors to explore the events of their pasts in texts that would also prove interesting and illuminating for their reading public. Yet the collaboration by literary authors such as Wolf and Müller in the early GDR years, and by Anderson and Maron in the later years of the GDR, made the ethics of this mode of autofictional writing especially problematic. Could these former IMs be trusted to render an authentic account of their espionage for the Stasi? The problem did not only affect the reception of works by former IMs. The GDR's literary sphere had been infused by Stasi espionage, and while some authors had participated in it, all authors writing during the GDR years had been victims of the Stasi. Therefore the questions about literary form and ethics that were raised by these works became even more fundamental. What becomes of life writing when a secret police has intervened heavily into the life of which one is trying to give account? What is the author to make of her own life-story that has been so shaped by the work of an agency that is, sociologically speaking, a black box (its workings are invisible)? Given the troubling of such fundamental bases of accounting and accountability on which life writing relies, the works of autofiction published after 1990 undermined the possibility of comprehending the recent past within clear categories, whether they be of victimhood and perpetration, participation and resistance, or the basic categories of fact and fiction on which the contract between author and reader rests across the whole of literature.

Given these factors, it is no wonder that the literary scandals of the 1990s dominated the front pages of German newspapers even more than the IM revelations in other areas of society. Moreover, there is a further factor that troubled the texts that were published at this time, which concerns the capacity of the individual to consent to or refuse participation in its society. More often than not, the central characters of these part-fictional, part-historical works fall into collaborations over which they do not have control. They suffer 
out-of-body experiences, or carry out involuntary actions that undermine their integrity and capacity to act for themselves. The appearance of ghosts, fantasyfigures, and Doppelgänger in these texts, and the attendant aesthetic disruptions and distortions of their settings, combine to warn their reader against entrusting too much, not only to a singular, authentic version of the past, but also to the subject's agency to define its position in that past as resistant or conformist. These disruptions give rise to a further defining tendency of these works, namely that their narrative voices and perspectives shift almost incessantly, so that external focalization on a third-person protagonist suddenly switches into the interior monologue of a highly unreliable narrator and vice versa. Thus the narrative techniques, on which readers rely to find a route into the inner world of characters, operate in these works to reveal such an inner world to be very complex indeed. It is through such devices that the writing of German unification presents its characteristically nuanced handling of the question of collaboration. Most crucially of all, these are texts that in their aesthetic forms and ambiguous plots also pose a challenge to dominant categories of the society that came after the Stasi. For one of the strengths of this corpus of works is to present collaboration with the Stasi and SED not as shocking exceptions, but as behaviors compatible with broader traits of subjectivity in late modernity, traits that result from the demands that modernity places on its members to submit to authority, to participate in social and economic processes of domination, and thus to collaborate in the undoing of their own freedom. In this sense, the writing of East German authors after unification has maintained the critical imperative that existed in the GDR, and indeed taken it forward into the time after the Stasi, to consider the implications of Stasi collaboration for modern subjectivity at large.

\section{Collaboration as a challenge to the sovereignty of subjectivity}

Few East German writers publishing after 1990 are content to locate their IM characters within neat ethical categories of participation or resistance to the Stasi. While certain narratives of the immediate post-unification moment set out the perspectives of individuals who were definably perpetrators or only ever victims of the former regime, most post-unification works set in the GDR depict characters who stood somewhere between those two positions. As such, these works also favor plot scenarios that implicate their characters in collaborations that occur outside official SED or Stasi employment, and in relation to 
which they themselves are ambivalent or only partially aware. In this manner, East German prose has revealed collaboration as an interaction between subject and society in which the most complex aspects of human agency come to the surface. Many of the collaborator-figures in these works find that their actions have unpredictable consequences, or that they bring them face to face with lost memories or intersubjective dramas that they could not have foreseen when signing up. Collaboration in such cases appears as a psychic event in which the subject does not have agency over its decisions, and is instead delivered over to the content of its unconscious mind, including those identifications and attachments that bind the subject to others, especially to figures of power.

That the civilian arm of the Stasi would not have been entirely in control of its own actions did not occur to the Ministry itself, as it developed systems for selecting and testing an army of spies to whom its most delicate work could then be entrusted. Curiously, the idea is also largely absent from historical accounts of the IM, including the recent work of Ilko-Sascha Kowalczuk, who sets out to offer a much-needed, measured reassessment of the Stasi's regime of suppression. Kowalczuk bypasses the more complex implications of the IM phenomenon, to advocate instead only a very thorough examination of the facts contained in a given IM’s spy file, assessing "das konkrete Tun des Einzelnen” (what individuals did, in a concrete sense; Kowalczuk, 2013, p. 214). The principle for Kowalczuk is that if enough information is gathered about the intent and the acts of a given IM, and if that information is viewed in the context of their broader behavioral patterns, it will be possible to gain a full picture of the collaboration. Matthias Wanitschke has come closer to addressing the complexity of collaboration in his examination of the Menschenbild (image of the individual) that the Stasi held. Wanitschke proposes that the Stasi's view of a society that could be ruled as a collectivity failed due to a basic autonomy in the make-up of human beings. Where the Stasi operated on the basis that any individual could be manipulated into participation if its techniques were sufficiently developed, Wanitschke maintains that the human subject is too fundamentally "frei, selbstbestimmt zu handeln" (free to define their own behavior; Wanitschke, 2001, p. 14) to be co-opted in that manner, a factor that in his analysis finally thwarted the Stasi's aims.

Such strength of individuality and self-definition, claims Wanitschke, held firm in many cases during even the darkest years of surveillance and suppression in the GDR. Yet there seems to remain some doubt in Wanitschke's analysis, concerning whether or not the subject acting in the context of the Stasi, and even after its dissolution, is necessarily able to grasp the freedom of self-definition 
that is in principle available to it. He writes that everybody who lived as an adult in the GDR must face "die individuelle Gewissensfrage, ob man sich damals an die befohlene Norm anpasste oder sich seine Identität entgegen der staatlichen Gleichschaltung zu bewahren versuchte" (the question of individual conscience, whether one conformed to the norm demanded back then or whether one tried, in opposition to the cooptation that was being enforced by the state, to preserve one's own identity; ibid., p. 13). Moreover, he writes, this question continues into the present day, so that it remains the responsibility of each subject to consider "ob man sich auch heute in einer offenen Gesellschaft [...] selbstverantwortlich verhält oder sich—wovon auch immer-fremdbestimmen lässt" (whether [...] we behave with self-responsibility today, in an open society, or whether we let ourselves be defined by whatever it may be; ibid., p. 13). Wanitschke's analysis of the Stasi's inaccurate, because too collective, Menschenbild approaches a crucial topic for understanding how collaboration comes to take place: does the subject define the course of her own life, or are others deciding it for her, in some fashion that is more collective than the individual will? Yet Wanitschke's reading still neglects those aspects of the human subject over which it does not and cannot decide, namely the latent content of both personal and collective memory, as well as those desires and attachments that motivate its actions from a place of unconscious agency, none of which can be fully overseen. These are the aspects taken on by the literary writing by East German authors after unification, as they address themselves precisely to that lack of overview in the self, which causes the subject to act out of its own control, and to be susceptible to the manipulation of others, both within and after the Stasi's reign.

The chapters that follow offer a new approach to collaboration in the GDR shaped by the insights of cultural theory and philosophy since the late nineteenth century. The psychoanalytic theories of Freud, and of his mentor Jean-Martin Charcot and colleague Josef Breuer, and their adaptation in the later twentieth century by Jacques Derrida prove fruitful for plotting out the unconscious identification that leads to collaborative attachment in literary writing after unification. Further illumination is provided by the recent intellectual histories of Ruth Leys, who sets out the legacy of psychoanalysis in contemporary cultural studies, and by Judith Butler, whose writings on gender, war, and moral philosophy apply psychoanalysis, among other theories, to contemporary phenomena of subjectivity in its collective contexts. These psychoanalytic and psychoanalytically informed theories enable the analysis that follows to elaborate behaviors of the subject that fall outside of empirical views of human behavior-empirical views that the Stasi itself would have 
found acceptable, with its teaching of Marxist-Leninist "materialism" at the Juristische Hochschule.

In fact, a psychoanalytic view of the subject was not common anywhere in the GDR, where a preference for Pavlov's teachings had been pronounced at a conference held in Leipzig on 15 and 16 January 1953, after which practitioners of psychotherapy were required to follow Pavlov's teachings, including their condemnation of psychoanalysis. One of the few therapists who attempted nonetheless to apply psychoanalytic methods in the GDR, Hans-Joachim Maaz, described Pavlov's behavioral theories perspicaciously as suffering from a "konfliktdämpfende Orientierung" (tendency to stifle conflict; Maaz, 1990, p. 195). Indeed psychoanalysis, with its approaches to repression, to matters of the taboo and the secret, posed too great a risk to the SED dictatorship, for which any questioning of the psychodynamic functions of power within the medical establishment, as anywhere else, would have been incendiary. While mindful of this resistant potential of psychoanalytic thought, the book also engages with Michel Foucault's spatial analysis of power, and Walter Benjamin's radical cultural critique, theories from outside of the psychoanalytic canon, which enable further navigation of the states of participation and refusal, collectivity and individuality, that structure the East German texts as they plot the complex and ultimately intersubjective dynamics of collaboration.

The intersubjectivity of collaboration is evident from the etymology of the term, as a co-labor or working together of interlinked subjects or groups, a gesture that does not have to be negative, and indeed is necessary to the formation of societies. Mark Sanders recognizes the necessity of a similar working-together in his book on Complicities, in which he focuses on the role played by intellectuals in upholding South African apartheid. Sanders analyzes complicity as the symptom of what he terms a basic "foldedness in human being" (Sanders, 2002, p. x). Foldedness is a structure of connectivity that for Sanders is the very "condition of possibility for any opposition to a system that constantly denies it" (ibid., p. x), a denial that in turn renders complicity not only inevitable but also potentially resistant, as an expression of loyalty or solidarity, if only the forces to which the subject lent its complicity were not those of apartheid. As shall become clear in the present book, such inevitability of connectedness with others, the necessity of working with them and attaching to them in groups and societies, places the Stasi collaborator in something of a trap. Moreover, and perhaps even more urgently, one of the thematic markers of East German writing into the new millennium is that collaboration continues as an inevitability in its literary plots long after the time of the Stasi is over. 
As it takes in the new environment of liberal democratic capitalism, post-GDR writing maintains plots and images of collaboration with regimes of power. The notion admittedly becomes more elastic in the years after German unification, so that where earlier texts refer to specific acts of collaboration in the Stasi past, more recent works turn to phenomena of participation in a variety of political, economic, and social processes that have arisen after the end of state socialism. These latter participations occur in contexts of personal and professional relating, but more commonly they figure as the more isolated decisions to engage in dominant markets of consumerism, or in the consumption of porn and striptease. They also encompass the knowing or unconscious participation in the new technologies of surveillance and archiving in which the contemporary subject is tracked in files that, as Heiner Müller predicted, may never be publicly opened. In what follows, I set out from Sanders's analysis in order to differentiate the terminology of collaboration from that of complicity, and thus distinguish these new forms of participation from the more active workingtogether of collaboration with the Stasi, as symptoms of a capitalist complicity that East German writing depicts as following soon after the Stasi's dissolution.

This new complicity is less actively connected than that which Sanders explores; indeed, its defining marker is the isolation that sets it apart from the interaction that IMs had with commanding officers who would woo them in a fashion tailored to their personality before asking them to sign paperwork explicitly stating their involvement. Complicity in the post-unification setting is even more invisible than was the work of the Stasi, but the urgency of addressing it is asserted convincingly by writers from the former socialist state. There is an increasing isolation of their characters in the corpus of East German writing as it enters the 2000s, and begins to track the acts of participation that transmute into a less connected, more abstract complicity that is not folded as in Sanders's account, but figures instead as a passive acting-in-participation with systems that are less embodied than was the Stasi, and so leave the subject to operate alone in a flat and empty environment. Whether East German writers prefer such acts of complicity to those that were carried out with the Stasi is unclear. These works of critical literature instead give us the insight that the newest complicities are intrinsically bound to the recent history of collaboration with the Stasi. Like the work of the IM, capitalist participation still-though perhaps imperceptibly_takes place in relation to others, still contributes to the maintenance of existing regimes that have collective consequences, even if those who suffer the worst of those consequences remain invisible.

An approach for articulating the relationship between individual participation and political collectivity is offered by a set of theories that cluster around the 
notion of sovereignty. In twentieth-century political theory, sovereignty (souveraineté; Souveränität) signified the integrity and authority of a nation-state. As such, it was a loaded term during the division of the GDR from the Federal Republic, which refused to recognize socialist East Germany as a sovereign state and to conduct talks with it on that basis. Sovereignty also relates to the specific gestures of enactment, discussed by Carl Schmitt and Walter Benjamin, that can be made by the figurehead of sovereign nations. Schmitt, a legal and political theorist whose membership of Hitler's National Socialist Party makes him a problematic if not taboo member of the Western cultural-theoretical canon, was familiar with the seventeenth-century discussions of absolute monarchy by Hobbes and others, and from their terms theorized the defining gestures of sovereign power that were relevant to the regime that the NSDAP was building. Schmitt's sovereign is known by his or her ability to decide "worin das öffentliche oder staatliche Interesse, die öffentliche Sicherheit und Ordnung, le salut public usw. besteht" (what public or state interest, public security and order, and the public good consist of; Schmitt, 1993, p. 13). In times of crisis, the sovereign can declare an Ausnahmezustand (state of exception), which calls a halt to the political order in order to protect the security of the realm. This particular decision articulates the limits of a national territory and thus divides the subjects who may reside within those limits from those who must remain outside of their protection.

Critiquing liberal democracy from the opposite end of the political spectrum, the Marxist cultural theorist Walter Benjamin responded to Schmitt's thought by exposing the "fürstliche Exekutivgewalt" (executive power of the ruler) that was exerted by the Hitler regime (Benjamin, 2000, p. 47), and the "Gebrechlichkeit der Kreatur" (fragility of the creature; ibid., p. 123), a metaphor for the vulnerable subjectivity of those who were governed by such violent force. Benjamin, who corresponded with Schmitt, pursued his interest in the underside of the gestures of totalitarian power that the latter propounded, and found in the process that the sovereign leader is a creature like any other. In this way, Benjamin identified a vulnerability at the heart of state power that offers a more liberatory prospect than Schmitt's totalitarian vision could. Giorgio Agamben's writing since the early 1990s has gone on to explore the applicability of these theories of sovereignty to the contemporary West, with its black zones, secret prisons, and other sites of political exclusion. The terminology of sovereignty theory is also found in the writing of Derrida, in particular his arguments concerning animal life as a constitutive counterpart to sovereign power in the last lectures before his death.

An approach to sovereignty that does not rely on the terms provided by Schmitt can be found in the work of Michel Foucault. It is common to distinguish 
an early Foucault, the scholar of orderly regimes of discipline in such studies as Madness and Civilization (1964) and Discipline and Punish (1975), from a "Foucault 2.0" (cf. Paras, 2006), whose last lectures on governmentality and late histories of sexuality traced the development of regimes characterized by a wider array of options for agency on the part of their subjects. However, what binds the two eras of Foucault's work is a concern with regimes of sovereignty. While in Discipline and Punish he considers its development into the orderly forms of modern regimes that he classifies under the term Discipline, his last lectures contrast the forms of ancien-régime sovereignty in pre-Revolutionary France with the more flowing, but still control-oriented systems of the then most current techniques of Biopower and Security. My aim in examining the Stasi in relation to these "schools" of sovereignty theory is to generate a political model through which to conceptualize the operations of the Stasi, including its place with the SED dictatorship. All of the key topoi of sovereignty as explored since Schmitt and Benjamin, including the decision, the limit, the state of exception, and the experience of creatureliness, as well as the architectures of governmentality that interested Foucault in his final lectures, appear in the writing of East German authors after unification. Their texts mobilize these terms in order to depict the effects of the Stasi's operations on its subjects, both on the victims of Zersetzung and imprisonment, and on those subjects who acted as its unofficial informants. As such, a reading of the Stasi in the terms offered by sovereignty theory enables, first, an understanding of what made the Stasi so successful as a secret service-one whose subject-focused techniques are emulated today by surveillance agencies around the world. Second, it offers a terminology for describing the precise manner in which the Stasi could be so successful in recruiting the numbers of collaborators that it did from within the civilian population of the GDR.

The return of the topoi of sovereignty in the writing of German unification provides an essential vocabulary that has been missing until now from existing accounts of the Stasi, both in English- and German-language scholarship. As I show in the following chapters, these images and concepts function in East German prose works to delineate the relative resilience or, more often, fragility of the subject captured in scenes of collaboration both with and after the Stasi. This vocabulary is unfamiliar to the Anglophone world but enjoys currency in contemporary spoken German, where the adjective souverän has an everyday usage denoting a state of self-possession, in which the individual can feel that their life is independently self-defined, and therefore resistant to co-option by others. Such personal Souveränität is something for which the characters of 
East German writing yearn during the dictatorship, as a result of the borders that it placed on individual lives. Thus, the first protagonist of Monika Maron's oeuvre, Josefa Nadler, longs to live not as one "der nur zweiköpfig denken kann, vierfüßig tanzen, zweistimmig entscheiden und einherzig fühlen" (who can only think with two heads, dance with four feet, decide with two votes and feel with one heart; Maron, 1981, p. 22). Instead, she strives to act as a whole individual, who can make decisions of her own. The poet Volker Braun, who unlike Maron was a decisive critic of the change to free-market capitalism in the former Eastern states, views such a desire for personal sovereignty much more sceptically in his ironic poem "Eigene Kontinuität" (Continuity of One's Own; Braun, 1979, p. 70), as a dogged desire for stasis that would ultimately be destructive.

Maron's protagonist's viewpoint was the more dominant after the fall of the Wall, such that East German writing plays host to a whole cast of characters who strive to grasp sovereignty of their own, hoping thereby to act with decisiveness and integrity in relation to their context. These qualities would represent a subjectivity quite different to that Kreatur of power which Biermann saw in IMs such as Sascha Anderson. Yet the possibility of such sovereignty and, as in Braun's poem, its ultimate desirability are also always in question in this body of texts. Within the dictatorship, but also after its demise, their characters instead continue to find themselves in scenarios of heteronomy, of that Fremdbestimmung or definition by others against which Wanitschke's subject naturally struggles, and yet which continually undermines the possibility of the modern subject's sovereignty over itself. Thus in the works presented here, sovereignty is an impossible desirable, a state that is sought but cannot be attained. If it were ever to be attained, moreover, this impossible desire, based in the same anxious longing for security that led to Stasi collaboration, would not offer any lasting benefit.

A theorist who has considered the notion that subjectivity desires its own sovereignty is Judith Butler, whose writing since 2000 addresses a subject who does not stay "intact" in relation to others (Butler, 2004, p. 23). Instead, Butler proposes an ethical model in which the understanding "that none of us is fully bounded [...] but, rather, we are in our skins, given over, in each other's hands" becomes "the basis of our accountability" (Butler, 2005, p. 111). Butler's subject is not separate from the power of others or the content of its own unconscious, and as such it must develop strategies for ethical action within these limits. The challenge to such an ethical programme arises, however, where the inherent unsovereignty of the subject presents itself as a susceptibility to be complicit 
with power. Such complicity was already at hand in Butler's work of the 1990s on the production of the individual by the speech acts and material phenomena of a strictly gendered social order. In Bodies that Matter, Butler argues that the subject's very being is acquired through a citation of that order, "a citing that establishes an originary complicity with power in the formation of the 'I"' (Butler, 1993, p. 15). Such inherent complicity, in the very formation of the subject, renders the "reworking of abjection into political agency" (ibid., p. 21), by the resistant "queerness" at the heart of Butler's gender theory, difficult from the start. Given the forms of the sovereignty that the Stasi was there to uphold, with its vast network of secret prisons and express goal of zersetzen, taking apart the dissident subject, the citation of such an order seems perilous indeed.

Moreover, the provenance of the modern theory of sovereignty, from the most influential Nazi legal theorist, means that there are certain additional risks attached to its application. For instance, in an article on Uwe Tellkamp's celebrated novel Der Turm (The Tower, 2008), David Clarke applied Agamben's theory of "bare life" (Agamben, 1998, p. 111) — those human lives that are most subjugated and injured by the sovereign power of Schmitt's leader-to the indignities suffered by Tellkamp's protagonist Christian Hoffmann in the GDR. Christian joins the Volksarmee in order to secure a place at university, and is later imprisoned. Clarke writes that, through these events, Christian "is reduced to a piece of bare life, which can be disposed of as that system sees fit" (Clarke, 2010 , p. 500). In an article in the same journal issue, I argued that the application of Agamben's theory of bare life to the GDR risked eliding different kinds of oppression, carried out in the name of opposing political ideologies (cf. Ring, 2010b, p. 518). On the other hand, Agamben's theory of the state of exception itself draws on examples outside of the concentration camps, including the black zones or secret prisons of capitalism. Contemporary Germanist Eric Santner's work also relies on a flexibility of categories to span across contexts where politics and techniques may differ, but certain spectres of past regimes remain. Thus to some degree, contemporary sovereignty theory allows for such comparisons and even relies on them for its own theoretical leverage. Given their basis in the analysis of the Holocaust, the challenge is to apply these theories differentially, in recognition of the very different political histories at stake and their varying human effects.

It became clear at the very latest in the autumn of 1989 that the Stasi had failed in its role of protecting the GDR's sovereignty. The sovereignty of the subject in this destructive setting was accordingly vulnerable to the kind of fragility that Benjamin was able to see, and against which, as Braun intuits in his 
poem "Eigene Kontinuität," the desire for a sovereignty of the subject is surely directed. The field of sovereignty theory has much to offer for understanding this ultimate failure of the Stasi, not least because it furnishes a vocabulary for describing the fragility of the subject that the Stasi held in its sights. To apply the terminology of these theories to sovereignty or unsovereignty of the subject is to offer an account of the Stasi's failure to capture and secure the human target of its operations. Moreover, the fragility that such an account uncovers is key to understanding the complicities that East German literature finds operating in its new setting, as iterations of an unsovereignty of the subject that has been there all along.

\section{Approaches to collaboration (1): Texts and regimes}

Chapters 1 and 2 present some of the first East German novels that were published after unification, including Maron's Stille Zeile Sechs (Silent Close No. 6, 1991), and Wolfgang Hilbig's "Ich" ("I") of 1993. The protagonists of these novels are collaborators with SED Party functionaries or with the Stasi, who participate in those regimes in a manner with which they are not entirely comfortable, but which they also find impossible to resist. These chapters provide a first approach to interpreting the means by which the individual became implicated in collaboration with the SED and Stasi. This approach is consciously intertextual, so that it sets these early post-unification works into a context of European and North American literatures since 1750 to which these East German writers refer, and whose themes of labor and resistance shed light on collaboration as a subjectivity-in-crisis with implications beyond the immediate East German setting.

These co-readings situate the early novels of German unification in a literary tradition that includes the modernisms of Kafka and Melville, and the canon of German Romanticism. Thus, alongside the East German collaborators in its primary texts, this first section also plays host to a cast of figures including Goethe's Faust, and one of the most cryptic characters of Kafka's oeuvre, Josef K. of Der Proceß (The Trial, posthum 1925), who provide models of counterintuitive participation in processes that cannot do them any good. Another figure of Kafka's, the undefined creature / sovereign of his unfinished short story "Der Bau" (The Burrow, posthum 1931), and the ultimate limit figure of German Romanticism, Kaspar Hauser, prove apt forerunners for the East German characters who struggle in the grip of dictatorship. On the other hand, 
Herman Melville's "Bartleby, the Scrivener" (1853) offers a rare model for the refusal to collaborate, one that admittedly pivots on the willingness of the dissident to die rather than collaborate. The East German writing of the early 1990s revisits these core figures of modernity for their portrayal of collaborators whose ghostly hallucinations disturb their bids for agency. It also cites the aesthetic techniques of modernism and Romanticism, their linguistic and symbolic fragmentations that can reflect the inner torment of the unwilling collaborator in the GDR. The first chapters evaluate the affordances of such a mobilization of literary tradition, and in so doing they set the focus in recent East German writing, on the ultimate unsovereignty of the human subject, in a line of inheritance beyond the immediate East German setting, into a whole canon of writing in which the individual struggles and fails to grasp control of its destiny, slipping instead into the most counter-intuitive acts of collaboration.

The section also considers the aptitude of a number of strands of cultural theory for understanding the interlinked processes of attachment and refusal that in these works are shown to underlie collaboration. Many of these theories are evoked by name or by association in the primary works, including the psychoanalysis of Freud and his colleagues, and the poststructuralist theories that traveled by various illegal and state-sanctioned routes into the GDR's literary underground. Given the perniciousness of the Stasi's techniques, that allegedly included the planting of these theories in the literary scene via IMs in order to prevent more direct forms of action against the regime, it is common to think of the Stasi as having created a world akin to the Castle and Court through which Kafka's last characters have to navigate. The vocabularies of Freud and Foucault have joined this vernacular for thinking about the Stasi after its demise, as an organization that operated "panoptically," or gave rise to behaviors that were "hysterical," "psychotic," or "perverse" on the part of its members. My approach takes these by now ingrained interpretations at their word, and in the process it enriches assessments of the Stasi as perverse or panoptic by reading closely the theories that the Stasi hoped would paralyze the SED's enemies, testing the applicability of these models, and thus the possibility of their recuperation for understanding the collaborative world that the Stasi created.

Crucial here are Freudian and post-Freudian accounts of hysteria, and Foucault's final lectures on Security, which were delivered from the late 1970s up until his death in 1984, and published in English translation between 2007 and 2011. In Chapter 2, citations from these lectures are set alongside detailed examinations of space and subjectivity in works by Hilbig and Kerstin Hensel, in order to offer new insight into which Foucauldian model of 
governmentality-Discipline, Security, or indeed Sovereignty-is most fruitful for reconstructing the power wielded by the Stasi. In its application of these theoretical approaches, the first section finally intervenes in the debate that continues in historical and cultural studies of the GDR, concerning the degree to which the SED regime can be understood as having been "totalitarian." This debate is related to the historical problem that haunts theories of sovereignty after Schmitt, and it poses one of the primary methodological difficulties in assessing the legacy of the Stasi, as part of a regime whose status remains in question.

Stuart Parkes has identified the associations of the term "collaborator," whose use introduces an "implication that the GDR was comparable in its iniquity to the Nazi era" (Parkes, 2009, p. 154). In line with such a comparison, historian and former BStU researcher Hubertus Knabe's introduction to a collection of writing by victims of the Stasi, Gefangen in Hohenschönhausen (Captive in Hohenschönhausen, 2007), frames the narratives contained within it as testimonies to the totalitarian nature of the former GDR, describing its crimes against the "Opfer der kommunistischen Gewaltherrschaft in Deutschland" (victims of the Communist reign of terror in Germany; Knabe, 2007, p. 18). GDR scholar Carol Anne Costabile-Heming, meanwhile, uses the term "totalitarian state" in her study of the SED's censorship regime (Costabile-Heming, 2000, p. 53). Certain continuities were indeed to be observed between National Socialism and the SED state, including the lack of democratically elected leadership in both regimes, and the persecution during the early 1950s of the GDR's small remaining Jewish religious community (cf. Ostow, 1990). ${ }^{1}$ Several hundreds of people were murdered by soldiers following the order to shoot at the border to the West, or suffered the death penalty, which was only abolished in 1987. However, to refer to the two German dictatorships, and thus categorize both as forms of one political mode of totalitarianism, risks a careless elision of two historically and ideologically distinct regimes.

As Michael Minden writes in his cultural history of modern German literature, there were considerable differences between the Hitler regime and the GDR. The latter state was "much less murderous" and "had deeper roots in historical causality than the death-obsessed Third Reich, as well as a theoretical concern for the welfare of the whole human race, and not just one part of it" (Minden, 2011, p. 160). Mary Fulbrook also rejects the trend of historical elision, arguing that the totalitarianism argument "served the Cold War purpose of conflating dictatorships of the Right and the Left under a common global label: the Soviet Union under Stalin and Germany under Hitler could be 
equated and castigated with scholarly impunity" (Fulbrook, 1997, p. 26). In line with Minden and Fulbrook, one of the aims of this book is to overcome the use of totalitarianism as a device of elision. It does so in its first section by returning to the definition of totalitarianism by the political theorist Hannah Arendt. Moreover, it does so in the company of works of East German writers who, more often than not, have avoided relying in their depictions of the SED dictatorship on the Nazi/Stasi comparison, that "festering half-rhyme" that Timothy Garton Ash finds attaching to Germany's recent history (Garton Ash, 2007, unpaginated). There are admittedly texts in which the risk of historical elision seems rather too close at hand. Maron's late GDR novel, Die Überläuferin (The Defector, 1986), which depicts the GDR as a camp walled in with barbed wire, and Kerstin Hensel's post-unification work Tanz am Kanal (Dance on the Canal, 1994), with its Stasi victim marked by a tattoo on her arm, present some of the riskiest examples. Yet in most post-GDR texts, the subject is decidedly located outside of the camp, residing instead in a context that is much more complex than that of genocide, and as such requires particularly careful handling if we are ever to understand the history of collaboration and resistance in the GDR.

\section{Approaches to collaboration (2): Reading the Stasi files}

The book's second section proposes that crucial context for understanding that history is provided by the Stasi's archive of files. In late 1991, the StasiUnterlagen-Gesetz (law concerning the Stasi files) made large sections of this archive publicly accessible for consultation, and applications from involved parties and researchers wishing to view the files began in January 1992. During forty years of surveillance operations, the Stasi had collected 158 shelfkilometers of archival materials (BStU, 2014, unpaginated). These include written spy reports, and the transcripts of surveillance operations, trials, and imprisonments. There is also a vast collection of procedural memoranda that were circulated among the Stasi's official members, concerned with the correct running of its operations, including collaborator recruitment, and countless photocopies of correspondence between citizens within East Germany and correspondence that was sent over the border into the West. The archival estate includes, too, the equivalent of 47 shelf-kilometers of documents on microfilm (the Ministry tended to destroy the paperwork on closed cases, but preserve their contents on microfilm for future reference), 39 million filecards, 1.8 million photographs, film negatives and slides, 30,300 video and 
audio recordings, and 15,500 bags of papers that were torn up as the offices were stormed in 1989. The book's third and fourth chapters consult some of these documents and images, taken from spy reports and files pertaining to the authors in question, as well as from the in-house documents of the Stasi's surveillance and archiving techniques. These files are set alongside the works of life writing that East German authors produced after their own encounters with the Stasi, as collaborators, victims, or tantalizing combinations of the two. The aim of this second section is two-fold: first, it identifies the historical documents crucial to tracing the cases of collaboration and victimization about which its primary authors write in their autofictional works after 1990. Secondly, and more importantly, these chapters assess the capacity of these files to decode the ethical dilemmas of the East German past.

The Stasi files offer concrete historical material, that contrasts with the literary narratives that often slip away after 1990 from clear ethical or aesthetic categorization. Yet this perspective comes with certain methodological problems of its own. The largest number of requests to view the files came from citizens who are affected by them, with a total of 6.5 million access requests being filed between 1991 and mid-2012, 486,000 of which related to criminal investigations and reparation cases (BStU, 2012, p. 11). The archive's opening provided access to documents without which legal justice could not be done. On the other hand, many documents were removed from the archive during the months following 1989, including those held in the thousands of sacks of torn papers that are still being pieced together by employees in Zirndorf, Bavaria. A computerized system is in development to reassemble the latter fragments, but the papers that Stasi officers managed to pass through a glue machine after shredding them will remain unseen. So too will documents that were allegedly confiscated by Western security services and may still be in use. Access to the documents that are in the archive is further limited, meanwhile, by regulations made in haste after unification, which divided the existing spy files into Täterakten (perpetrator files) that can be viewed by any visitor whose access application is successful, and Opferakten (victim files), access to which is only available to those defined as victims of the Stasi or, in the case of death, their next of kin. In this sense, the Stasi archive offers only a fragmented resource for understanding the history of collaboration.

In a Spiegel article concerned with Monika Maron's Stasi involvement, Wolf Biermann also reflected on the limitation of the files as historical documents since, he writes, they could never give an account of the "lebendigen Erfahrungen" (living experiences) of their subjects (Biermann, 1995, p. 44), 
but merely render "ein Flachbild" (a flat image) of them (ibid., p. 44). Literary scholar Michael Haase has questioned the kind of knowledge that can be gained by reading the documents of an "Überwachungs- und Repressionsbehörde" (office for surveillance and repression; Haase, 2001, p. 12). Indeed, the records that were kept by a spy organization such as the Stasi must be read with care. Yet the case for reading the literature of German unification in concert with the Stasi files has been convincingly made. In an essay on autobiographical writing by women after 1990, Karen Leeder finds that Günter de Bruyn's notion of a "Mißtrauen gegen mich selbst" (mistrust towards myself) had wide applicability to life writing emerging after unification (Leeder, 2000, p. 256). Leeder shows how literary autobiography became "porous to outside influences" (ibid., p. 260), and as such underwent a "hybridization of genres" in the time following unification (ibid., p. 259). Even beyond the gender of its authors, it seems that the new political environment spawned a kind of genre-trouble, as writers had to take account of the information made available by the publication of the files, of which their readers would now be aware.

As a result of the presence of the files in the post-GDR environment, Leeder argues that they form a necessary context for reading autobiographical or other modes of life writing after unification:

It is not one that can replace the published literary texts, but rather one which must be read alongside-in that the files make explicit the schizophrenia at the heart of, but so often suppressed by, forty years of GDR literature. (ibid., p. 257)

Sara Jones has argued meanwhile that the files can be viewed as one "source" of life writing (Jones, 2010, p. 197), which can shed light on aspects of the past that remain hidden within other texts. Jones draws on Alison Lewis's suggestion that a reading of files alongside literature should consider the file a form of "hostile, unauthorized biography" (Lewis, 2003, p. 383), in which the reports are deliberately intended to damage and manipulate their unwilling "protagonists" (ibid., p. 385). The second section of this book takes account of the approaches suggested by Leeder, Lewis, and Jones. It also goes beyond viewing individual spy files alongside the literary works of their subjects, in order to introduce a selection of the training memoranda, research documents, and Guidelines that were kept by the Stasi's internal departments, and which show the Ministry perfecting its techniques of recruiting unofficial collaborators and maintaining its archive of spy files. While it is questionable as to how reliable the contents of the files could ever be for the legal illumination and resulting justice that victims desired, when set in dialogue with the literary works of East German authors 
who encountered the Stasi as victims and as collaborators, the files nonetheless offer rich material for grappling with the consequences of the Stasi's regime and the ethical implications of collaboration with it.

Through their readings of previously unseen and untranslated procedural documents, Chapters 3 and 4 are able to track the practices through which the Stasi sought and yet failed to maintain an image of its victims and unofficial informants, and thereby of itself as an organization. What we find in the Stasi's procedural archive is a persistent striving for wholeness, for the completion of an image of the subject whose coverage should ideally be "lückenlos" (gapless; BStU, MfS, HA IX, Nr. 16034, p. 3). The works of life writing by former Stasi spies and victims consulted in these chapters evidence a certain level of success in the Stasi's aim for a gapless knowledge of its subject. On the other hand, the primary texts in these chapters also develop the image of a subject that ultimately resists containment in textual systems, in a manner that may well have brought about the failure of the SED system as a whole. It is not that this subject has no consistency whatsoever: neither the protagonists of Maron's or Christa Wolf's works quite fit with the systems that the Stasi put in place for managing them as unofficial collaborators, but nor were they completely unable to deliver the spy reports requested of them; meanwhile certain of Hilbig's autofictional characters muster enough resilience, as Hilbig himself did, to resist the imperative of collaboration with the Stasi to a certain degree. Yet the literary characters and indeed the historical figures who people this section do not hold together in the manner that the Stasi hoped, with its surveillance and archiving systems that were aimed at a totality of knowledge. The consequences of the subject's lack of hold in the face of these systems are ambivalent. It can lead in some cases to a rather too quick willingness to collaborate if it means the opportunity to travel and research, and publish literary works. In the case of the Stasi's victims, a lack of subjective "hold" may also mean falling apart under the pressure of Zersetzung or imprisonment. Such an ambivalence, of the subject that does not hold together with totality, is reflected meanwhile in the form of the works that are consulted in this section, works that have the most problematic status of all of the texts that came out of German unification.

That is because the texts consulted here are prose works whose characters and plots map onto the lives of their authors, yet whose literary qualities allow the events of the past to be re-imagined and explored in a complexity that sits on the edge of ethical defensibility. While Maron and Wolf reproduce documents relating to their own involvement with the Stasi in factual volumes, and both write in an autofictional prose that addresses these collaborations directly, Hilbig 
allows his characters to cite and mimic the language of the files within clearly fictional prose works. In all cases, the authors' use of the files works to problematize the authority of textual evidence with regard to the East German past. This is productive in the sense that the problem of the legibility of the subject raised in these works, of identifying subjects of surveillance or collaboration and recording the details of their lives in a gapless textual archive, presented a strategic problem for the Stasi's surveillance project itself, as it attempted to measure and categorize physical characteristics and social behaviors that could never be pinned down in their entirety. Yet such problematization brings with it a concurrent problem in reading the past, in grasping the kind of harm that was done, and the degree to which such harm was deliberate on the part of either official or unofficial spies. The chapters in this section cannot solve this latter problem; however, they provide approaches to it, informed by the models of subjectivity and of textuality offered by the literary works by East Germans after unification and by the theoretical and literary canons on which they were seen to draw in the first two chapters. These models enable us to assess both the potential for resistance and the collaborative risk that attach to the figure of the IM-a potential and a risk that persist, moreover, in the new setting of unified Germany.

\section{Approaches to collaboration (3): Capitalist complicities}

Chapters 5 and 6 are dedicated to the writing that East German authors continued to publish in the later 1990s and into the 2000s. When viewed together as a body of post-GDR literature, these works generate a haunting perspective on the new scenarios of political and personal compromise that their authors depict as underlying the new environment of liberal democratic capitalism. In the Federal Republic, the decisions that these literary characters can make are different, and they may hold the opportunity for more sovereignty, in the sense of deciding power over their lives. However, the characters of the latest East German texts also observe the limitations of that new sovereignty, in certain subject-internal conditions, not least the counter-intuitive operations of the unconscious, as well as external processes that these works depict. Central here are the dilemmas that they face regarding complicity with the new state and corporate bodies of the Federal Republic.

Charity Scribner's Requiem for Communism analyzed responses in German literature, visual arts, and cinema to "the socialist crisis" that followed unification 
(Scribner, 2003, p. 9). By examining works that look back in "collective sorrow" at East German socialism (ibid., p. 3), Scribner addressed herself to the Ostalgie, or nostalgia for the East, that became a critical watchword of the 1990s and early 2000s, leveled against former East Germans who were perceived as too slow in letting go of the GDR. The accusation was that certain groups were reluctant to relinquish the image of a GDR golden era that had never been, a hesitancy apparently expressed in the post-unification popularity of GDR consumer goods, as well as the successful cinema comedies set in the former socialist country, Sonnenallee (Leander Haußmann, 1999) and Goodbye, Lenin! (Wolfgang Becker, 2003), the latter directed by a West German but still considered a touchstone example of ostalgic culture. Historian Stefan Wolle's thorough history of the GDR, published at the close of the 1990s, aimed at debunking a myth of Die heile Welt der Diktatur (Ideal World of the Dictatorship, 1999), to which East German culture was apparently attached. Yet, as Scribner argues, and as the texts consulted in this book's final section attest, the cultural production of the post-GDR years did not exhibit any simplistic longing for the return of Soviet-style state socialism. Scribner's Requiem focuses on a complex collective affect, in which the socialism that had collapsed could be at once mourned and yet still hated for its abuses. The literary texts of East German authors belong to such a memory-work, as cultural products of a socialist memory that is inconsistent, selective perhaps, or perhaps perfectly able to handle the ambivalence of the end of a repressive regime that also signified the loss of a dream.

In the year 2000, critical theorist and Russia specialist Susan Buck-Morss published a work that deconstructed "the Cold War discursive binary of totalitarianism versus democracy" (Buck-Morss, 2000, p. xii), by claiming that both communism and capitalism represented two forms of a single "utopian dream" (ibid., p. xiv). Each aimed in the latter part of the twentieth century to generate "happiness for the masses" (ibid., p. xiv), and crucially, each failed, resulting in the loss of both dreams, first with the collapse of the Soviet bloc and secondly with the incapacity of capitalist democracies to deliver the "utopian potential" that industrial modernity had once seemed to promise (ibid., p. 3). In Buck-Morss's analysis, the post-Cold War age does not only mourn the state socialism that it recognizes as having failed; it also mourns the miscarriage of its Western counterpart, that utopia that has ended in the crisis of global capitalism. In line with Buck-Morss's analysis, East German authors are far from ostalgic in the terms bandied around in the anti-GDR hype of the 1990s. Instead, they favor plots and images whose complexity expresses the breaking 
of the spell of capitalism's once-utopian appearance with a sophistication only increased by its lack of certainty about what a solution might be.

Chapter 5 takes a close look at one such image, which is initially puzzling in its dominance in recent texts. The chapter takes its cue from the animals that appear with spectacular regularity in works of East German writing from the mid-1990s onwards. These images shed light on a particularly enigmatic aspect of the sovereignty theory that Benjamin developed, namely that state of subjection to bodies of power that is understood as creatureliness: the being subjected to-or even created by-certain regimes of power, as well as that animal aspect of the human self that is simply subjected to the contingency of its own life. The literary characters of unified Germany should, at the very least by the turn of the new millennium, enjoy a new freedom to assert agency over their lives. The GDR's regimes of surveillance and censorship are now decisively gone, and thus the struggle in these settings for a subjectivity that is bordered off from others and can decide on its own definition is certainly less intense. Yet the entomologists and arachnologists in these latest works, the dog- and cat-lovers, and the subjects who experience their own being as a state of animal subjection signal a continuing problem of sovereignty that takes on new forms in the capitalist context.

In the light of these new images in East German writing, it becomes even more problematic to read the GDR as an exceptional environment, a "totalitarianism" that suppressed some natural freedom, which could be enjoyed by the individual subject if only it were freed of surveillance. On the contrary, in these works subjectivity always takes the form of subjection, whether that be to the demands of collectivity - the family, the workplace, the free market economyor to the individual limitations of language, of desire, and other forms of human frailty. One such frailty is the continuing tendency of subjects to participate in the most destructive processes of their society. This tendency forms the focus of the final chapter, with its reading of Hilbig's final novel, Das Provisorium (The Stop-Gap, 2000), of the last stories published during his lifetime, and of the short prose works discovered in his literary estate. These texts are some of the most shattering works of the unification era, and they are written in Hilbig's characteristically dense prose that nonetheless delivers with searing clarity a vision of the complicities to which the subject of contemporary capitalism is vulnerable.

Certainly, the new complicities that these ex-East German characters enact are of a different nature and have different consequences to the collaborations that took place under the Stasi. Yet, in these final chapters, the book makes the 
case for the persistence of the problem of sovereignty that is articulated in these texts into the capitalist present, and thus the case for the ongoing urgency of the specific insights of East German literary writing. Emerging as they do out of the lost utopia of state socialism, the works visited in this study offer insight into the limited degree of agency that subjects of modernity can truly have, the limits on their genuinely consenting to participation, or indeed their carrying out effective acts of resistance. As such, if we are willing to hear it, they have a message to impart concerning not only the harm that was done by the Stasi's agents, but also that which we risk as agents of more contemporary regimes.

\section{Note}

1 Ostow's essay traces the vicissitudes of the SED leadership's attitude towards the Jewish community in the GDR. The SED state officially denied eastern Germany's guilt for the Holocaust, and relationships with the Jewish community remaining in East Germany were strained, albeit to differing degrees in different phases of the SED-regime. Thus in the early 1950s the SED carried out anti-Jewish purges in mimicry of those that Stalin was ordering across the USSR. Yet, after Stalin's death and a policy change in June 1953, there were moves to make remaining Jewish residents welcome in GDR society. After this point, grants were provided to repair synagogues, maintain kosher butchers and Jewish cemeteries, and special pensions were created for Jewish families due to their victimhood under National Socialism. In 1967, the USSR and the GDR took a pro-Arab, anti-Israel stance, which led to an increase in hostility towards the Jewish religious community; however in the years of Honecker's rule, relations improved once more. Honecker's GDR profiled its friendly relationship with its Jewish community as proof of a truly anti-fascist society-for instance, a large commemoration of Kristallnacht was organized in 1988, coinciding with the GDR's bid for the status of "Most Favored Nation" with the US. 